\title{
Pediatric sarcoidosis: report of seven cases
}

\author{
Yépez Ricardo*, Malagon Clara, Olmos Carlos \\ From 18th Pediatric Rheumatology European Society (PReS) Congress \\ Bruges, Belgium. 14-18 September 2011
}

\section{Background}

Sarcoidosis is a rare chronic granulomatous disease of unknown cause. It involves different organs and shows a variable clinical presentation according to the age of onset. High index of clinical suspicion and a positive biopsy are needed to confirm the diagnosis. Immunosuppressive treatment is required. The type of organs affected and response to treatment determine prognosis.

\section{Aim}

To describe the clinical features and course on a cohort of Colombian children with sarcoidosis.

\section{Methods}

Retrospective descriptive study at 4 pediatric rheumatology centers in Bogota

\section{Results}

$5 / 7$ patients had early onset(before $5^{\text {th }}$ birthday) another 2 had late onset sarcoidosis. All patients had a delayed diagnosis and were treated for other diseases. Early

\section{Table}

\begin{tabular}{lll}
\hline & Early onset & Late onset \\
\hline Sex(F:M) & $1: 1.5$ & $1: 1$ \\
Mean age of onset & 2,8 & 6 \\
Skin & $100 \%$ & $50 \%$ \\
Lungs & $40 \%$ & $50 \%$ \\
Mediastinal & $0 \%$ & $50 \%$ \\
Joints & $100 \%$ & $50 \%$ \\
Eye & $80 \%$ & $50 \%$ \\
Fever & $80 \%$ & $0 \%$ \\
Mean time to diagnosis(years) & 3,8 & 3,5 \\
\hline
\end{tabular}

\footnotetext{
*Correspondence: ricyepez@gmail.com
}

Pediatric Rheumatology fellowship program, Faculty of Medicine, Universidad el Bosque, Bogotá, Colombia onset sarcoidosis was more multisystemic. Arthritis and uveitis were more common. The triad of: skin, joint and eye compromise was observed. The frequency of lung involvement was similar on both groups and 1/7 had mediastinal involvement. No patients with Löefgren triad were identified. A course with flares and remissions was a cardinal feature.

\section{Conclusion}

Sarcoidosis shows variable clinical presentations. Early onset sarcoidosis presented more febrile and multisystemic than late onset. Joint, eye and skin were more common. Histological confirmation is needed to rule out other entities. Chronic uveitis and polyarthritis determined poor outcome. Chronic course was associated with worse prognosis.

Published: 14 September 2011

doi:10.1186/1546-0096-9-S1-P38

Cite this article as: Ricardo et al.: Pediatric sarcoidosis: report of seven cases. Pediatric Rheumatology 2011 9(Suppl 1):P38.

Submit your next manuscript to BioMed Central and take full advantage of:

- Convenient online submission

- Thorough peer review

- No space constraints or color figure charges

- Immediate publication on acceptance

- Inclusion in PubMed, CAS, Scopus and Google Scholar

- Research which is freely available for redistribution

Submit your manuscript at www.biomedcentral.com/submit

\section{() Biomed Central}

